INTERACTION: Jurnal Pendidikan Bahasa Vol. 7, No. 1; Mei 2020

ISSN: 2406-9558; E-ISSN: 2406-9566

\title{
An Analysis of Grammatical Errors in Song Lyrics
}

\section{Lulu Jola Uktolseja}

1ulujola39@gmail.com

\section{Universitas Victory Sorong}

\begin{abstract}
This research is a descriptive research with the aim to analyze the grammatical errors in song lyrics. Since the grammar elements are very important to note in order to be used appropriately. It also becomes very critical if English learners cannot distinguish every word or sentence that is heard through movie or music. In this research, the data is a kind of text, thus the writer uses the documentation technique. The samples of this research are nine songs from eight popular singers i.e Justin Bieber, Beyoncé, Rihanna, Lady Gaga, Miley Cyrus, Alicia Keys, Kesha, Katy Perry \& Juicy J. The technique of collecting data is documenting the songs from all the singers. The steps of doing this research are: Identifying, Classifying, Interpreting, Describing, and Concluding: the writer finds the conclusion and gives the suggestions. The result of this research, there are several grammatical errors in songs such as Conditional Sentence, Subject-Verb Agreement, Pronoun, Negator and Auxiliary Verbs.
\end{abstract}

Key words: Grammatical Error, Song, Lyric

\section{INTRODUCTION}

English applies as foreign languages in Indonesia while mostly Indonesian still use Bahasa Indonesia or their mother language as their everyday tools of communication (Devie \& Rohmah, 2019). Hence, the people of Indonesia are mispronouncing very often. This becomes even higher due to the lack of understanding of grammar, and coupled with inaccurate English learning resources, for example songs that are often listened to and sung. The song is very often used as a source of learning English because it has meaningful lyrics and interesting tones. The failure of the learning process is the inaccurate implementation of techniques with needs (Uktolseja \& Manuhutu, 2019). When Indonesian people as English learners, who are foreign languages in their country, learn English using song listening techniques where the lyrics are not correct according to grammar, it will have a fatal impact on the development of those students in oral and written. The language development will be inappropriate, so that in the future it will interfere with social interaction when they will use the language. Language plays an important role in society particularly to build social interaction during social communication (Uktolseja, Sujaja and Matinahoru, 2019). Grammar is an important and necessary skill that a student must have (Gunn and McCallum, 2005). English has a lot of grammar elements that are very important to note in order to be used appropriately. In Indonesian, we do not know so many grammatical elements so 
that when learning English mistakes in grammar are common. It also becomes very critical if English learners cannot distinguish every word or sentence that is heard through movie or music. Many songs are sung by students' favorite singers that are not in accordance with the proper grammar. This is created by the songwriter so that the rhyme produced is in accordance with the aesthetic requirements of the song. When the error is not corrected, the mistake or error will occur repeatedly both spoken and written English. Language can be studied further by applying a scientific study of language which enables people to analyze language called linguistics (Aldorio Petra, 2018). When students see firsthand the mistakes in the songs that are usually sung then they can renew and improve their English language skills. In this study used some classical pop, rock, R'n'B, indie and folk songs that are famous and are usually listened to even sung by students. The objectives of this study are to analyze and explain the types of grammatical errors in songs based on the rules in grammar.

\section{LITERATURE REVIEW}

\section{Previous Related Study}

Fenetta's (2016) research entitled "Grammatical Errors in Will I Am Songs" is a result of an observation about the errors found in song lyrics. The objects of this study are the phrases, clauses and sentences taken from lyrics of songs by Will I Am. The purpose of this study is to find out the types of error that occur in the song and to find the causes of the errors. The analysis concludes that the errors found in Will I Am's songs are influenced by external factors which are society and profession. This study is different with Fenetta's study. This study will analyze several songs which is not only by one Singer. This study discussed the errors based on the rules of grammar.

Wiyogo Purnomoadjie \& Mulyadi (2019) conducted a study entitled "A Syntactical Analysis on Sentence Structure Used in Two Adele's Songs. This research aims to describe the sentence structure through a tree diagram and to find the sentence structure appears in two Adele's song, especially in writing a descriptive text. This research employs a descriptive qualitative method. From the two of Adele's songs used as the samples in this thesis, grammatical sentence mostly appears rather than an ungrammatical sentence. Through the discussion, the researcher also found the substandard English words, such as Ain't, you'd, I'll, you're, didn't, couldn't, isn't. This study is different with Wiyogo and Mulyadi's study. This study did not only discuss about the abbreviation.

\section{The Theory of the Variable}

\section{Song}

Griffee (2001) mentioned that song is part of music that is formed through words that aims to be sung. A song is a composition of voice performed by a singer or by musical 
instrument. There are many messages delivered in a song (Hariyanto, 2017). The lyrics are included in song are printed as a form of communication between the author and the readers (Firdaus, 2013).

\section{Grammatical Errors}

According to Greenbaum and Nelson (2002), grammar refers to the set of rules that allow us to combine words in our language into larger units. Errors were considered as being the result of the persistence of existing mother tongue habits the new language. Greenbaum and Nelson (2002), grammar refers to the set of rules that allow us to combine words in our language into larger units. Some combinations of words are possible and others are not. According to Brown (2007) errors are the result of one's systematic competence. Hence, grammatical error is an error which is grammatical rules unsuitable that impacted the sentence uttered become not good. Error analysis is a term that when applied to numerical analysis refers to the mathematical analysis that describes the various aspects of error behavior in numerical methods (or algorithms). According to Ho (2005), there are four taxonomies of errors that contain parts of speech. They are errors regarding nouns and noun groups, errors regarding verbs and verb groups, error regarding preposition, and error regarding sentence structure.

\section{METHOD}

\section{Design and Samples}

A research design is a plan or strategy for conducting the research. According to the purpose of this problem, this research is a descriptive research. Arikunto (2007) states that descriptive research has not purpose to test the certain hypothesis, but just describe some variable and condition naturally. The researcher used documentation method as the way to collect the data because the researcher collected the data from songs. According to Arikunto (2006:321), study document is getting the data about case or variable as note, transcripts, book, magazine, etc.

\section{Instrument and Procedure}

Airasian dan Gay (2000) stated that instrument is a tool that is used in collecting data. In this research, the data is a kind of text, thus the writer uses the documentation technique. Sugiyono (2008) stated that documentation can be written and picture by someone that can be used to obtain information. Arikunto (2006) states that documentation technique is used to get data from variables: notes, books, transcripts, magazines and so on. In this research, the researcher reads all the primary data that has been collected and analyzed them. The data of this research is script of several songs. The researcher took all the songs lyric from the website kapanlagi.com. 
INTERACTION: Jurnal Pendidikan Bahasa Vol. 7, No. 1; Mei 2020

ISSN: 2406-9558; E-ISSN: 2406-9566

\section{Data Analysis}

In analyzing the data, the researcher used descriptive analysis. The steps of doing this research are:

a. Identifying: the writer identifies the common themes in the song lyrics.

b. Classifying: the writer classifies the data based on Hogue's classifications i.e faulty agreement, wrong article, wrong verb tense, wrong word form, wrong word, word missing, unnecessary word, wrong word order, and ungrammatical punctuation.

c. Interpreting: the writer interprets the ungrammatical lyrics which are found in the English songs based structure.

d. Describing: the writer describes the correct grammars should be implemented in the English songs.

e. Concluding: the writer finds the conclusion and gives the suggestions.

\section{RESULT AND DISUSSION \\ Conditional Sentence}

The grammatical error was found in Justin Bieber's Boyfriend where the verse goes:

"If I was your boyfriend, I'd never let you go"

He used an incorrect form to indicate the conditional sentence. Instead of $\boldsymbol{I}$ was, he should have used I were. Using I were will show that the sentence goes to explain the presupposition of the songwriter.

\section{Subject-Verb Agreement}

Beyoncé's Irreplaceable also contains a grammatical mistake of tense, such as the one in the following verse:

"Because you was untrue Rolling her around in the car that I bought you"

She used an incorrect to be form (past tense) for the second person singular you. She should have used you were instead of you was.

The next song is Love Yourself by Justin Bieber. In this song, the grammar error appears in the pre-chorus of the song.

"My mama don't like you and she likes everyone And I never like to admit that I was wrong."

My mama is the third singular person, thus the correct word is doesn't in the third person singular but the songwriter used don't. it should be my mama doesn't like you and she likes everyone. 
INTERACTION: Jurnal Pendidikan Bahasa Vol. 7, No. 1; Mei 2020

ISSN: 2406-9558; E-ISSN: 2406-9566

The other example is in Rihanna's song Work the grammar error appears in the beginning of the song:

"You see me I be work, work, work, work, work, work"

The correct grammar for that line should be I'll be working or I'll be at work. The future tense will or adding the future tense will plus preposition at before work.

Pronoun

The pronoun grammatical error also found in Lady Gaga's Bad Romance. Especially in this following verse:

"You and $\underline{\boldsymbol{m} \boldsymbol{e}}$ could write a bad romance"

The pronoun in that verse shows the pronoun as subject. Thus, the lyric should be you and $\boldsymbol{I}$.

The next song is Wrecking Ball by Miley Cyrus. The following verse below shows that the lyric does not have pronoun, so it is incomplete.

\section{"Left me crouching in a blaze and fall"}

That lyric should be you/he left me crouching in a blaze and fall. Hence, the lyric will complete and correct.

\section{Negator}

Next song containing grammatical error especially for the negator is If I Ain't Got You by Alicia Keys.

"Some people want it all But I $\underline{\text { don't }}$ want nothing at all."

She used double negation in that verse. I don't want nothing is ungrammatical correct, because it wishes for the different meaning. It should be I don't want anything.

Another example is Tik Tok by Kesha.

"Ain't got a care in a world, but got plenty of beer. $\underline{\boldsymbol{A i n}^{\prime} \boldsymbol{t}}$ got $\underline{\boldsymbol{n o}}$ moneyin my pocket, but i'm already here"

The line says ain't got no money which according to the double negative means have not got no money, the lyric should be ain't got money or got no money. 
INTERACTION: Jurnal Pendidikan Bahasa Vol. 7, No. 1; Mei 2020

ISSN: 2406-9558; E-ISSN: 2406-9566

\section{Auxiliary Verbs}

In the song Dark Horse by Katy Perry \& Juicy J, there is a grammatical error occurs especially in this following verse:

If you get the chance you better keep her

She swears by it but if you break her heart

She turn cold as a freezer

In that verse, Juicy $\mathrm{J}$ told about something that Katy Perry potentially do in the future. Thus, the lyric needs auxiliary very will to complete the sentence. Hence, the lyric should be she will turn cold as a freezer.

\section{CONCLUSION}

The finding showed that there were five kinds of grammatical error which had been found such as Conditional Sentence, Subject-Verb Agreement, Pronoun, Negator and Auxiliary Verbs. The English learners should to know that sometimes the musicians used ungrammatical sentence in their songs to adjust the rhyme of the songs. It can be concluded that the grammar was still a problem in learning process, even the native speakers sometimes used ungrammatical words or sentence to put aesthetics value on their masterpiece. Otherwise, errors need to be handled, or they will become trouble in the other day. The English learners should be aware of what is going on especially about this error analysis and keep a keen eye on this thing, so it will not become problem in the future. Through this surface awareness, the language learner will not accept something she/he just heard, and use it all the time without knowing the truth. This is important so that no chain of grammatical errors is created.

\section{REFERENCES}

Airasian, Peter and L. R. Gay. (2000). Educational research: Competence for analysis an application (6th ed.). New Jersey: Merrill Prentice Hall.

Aldorio Petra. (2018). Grammatical Errors And Their Effectsin Rich Brian's Songs. An Undergraduate Thesis. Universitas Sanata Dharma, https://repository.usd.ac.id/33214/2/144214074 full.pdf.

Arikunto, S. (2006). Metode Penelitian Kualitatif. Jakarta: Bumi Aksara.

Arikunto, S. (2007). Prosedur Penelitian: Suatu Pendekatan Praktik. Jakarta: PT Rineka Cipta.

Brown, H.G. (2004). Prinsip Pembelajaran dan Pengajaran Bahasa. Jakarta: Pearson Education, Inc. 
INTERACTION: Jurnal Pendidikan Bahasa Vol. 7, No. 1; Mei 2020

ISSN: 2406-9558; E-ISSN: 2406-9566

Devie Reztia Anjarani, Rohmah Indahwati. (2019). An Analysis Of Students' Errors In Using Simple Past Tense In Translating Narrative Text. Prosodi. Vol. 13, No. 2, Oktober.

Fenetta, Alexandra. (2016). Grammatical Errors in Will I Am's Songs. Undergraduate Thesis. Yogyakarta: Sanata Dharma University, 2016.

Firdaus, E. A. (2013). Textual Meaning in Song Lyrics. Passage, 100.

Greenbaum, S \& Nelson, G. (2002). An Introduction to English Grammar (Second ed.). Essex: Longman.

Griffee, D. . (2001). Songs in Action. Hertfordshire: Prentice Hall International.

Hariyanto. (2017). The Analysis of Figurative Language Used in the Lyric of Firework by Katy Perry (A Study of Semantic). English Education: Jurnal Tadris Bahasa Inggris p-ISSN 2086-6003 Vol $10 \quad$ (1), 2017, 46-60. https://ejournal.radenintan.ac.id/index.php/ENGEDU.

Ho, C. (2005). Empowering English Teachers to Grapple with Errors in Grammar. Singapore: Nanyang University Press.

Sugiyono. (2008). Metode Penelitian Kuantitatif Kualitatif dan R\&D. Bandung : ALFABETA.

Uktolseja \& Manuhutu. (2018). The Use Of Whispering Team To Enhance Students' Listening Skill at Grade 6 Of Klasaman 2 Elementary School Sorong City. Getsempena English Education Journal (GEEJ). https://geej.stkipgetsempena.ac.id/?journal=home\&page=article\&op=view\&p ath $\% 5 \mathrm{~B} \% 5 \mathrm{D}=124 \&$ path $\% 5 \mathrm{~B} \% 5 \mathrm{D}=91,2018$.

Uktolseja L., Sujaja H. and Matinahoru M. (2019). A Contrastive Analysis Between English and Indonesian Kinds of Sentences. IJET (Indonesian Journal of English Teaching), 8(1), pp. 54-61. doi: 10.15642/ijet2.2019.8.1.54-61.

Wiyogo Purnomoadjie \& Mulyadi. (2019). A Syntactical Analysis on Sentence Structure Used in Two Adeles's Songs. PANYONARA: Journal of English Education Vol. 1, No. 1, September. 